\title{
Side locked headaches
}

\author{
A Momoh-Ojewuyi", A Ayubi, R Abusamra, S Al-Ani, A Whitehouse, R Alkilani, MAS Ahmed \\ From The European Headache and Migraine Trust International Congress \\ London, UK. 20-23 September 2012
}

\section{Methods}

Data were prospectively collected from 975 eligible patients (554 females; 583 Caucasians; age range $=4.5-18.1$ years) with headaches. Patients were included only if they were $>4$ years old and had suffered headache course for $>6$ months and or 5 separate headache attacks. We have adopted previous descriptions of terms for anatomical sites for location [1]. Side locked unilateral headache (SLUH) is defined as a headache that is for all time fixed unilaterally and never changed side. Headache diagnosis was made on the basis of ICHD - II, 2004 [2]. Headache diagnosis included migraine $(\mathrm{n}=585)$; tension type headaches $(\mathrm{n}=$ $234)$; other headache types $(\mathrm{n}=91)$ and remained unclassified in $65(7 \%)$ patients.

\section{Results}

119/975 (12\%) of patients experienced recurrent SLUH during a mean headache course of 2.3 years. It was more for unilateral SLUH to localise to the right than the left (60\% vs $40 \%)$. Topographically, temporal headache was the most frequent, followed by frontal and then parietal. Headaches were SLUH in $11.5 \%$ of patients with migraine; $8 \%$ with TTH and $23 \%$ patients with headache that not yet specified. Brain imaging was normal or showed no significant abnormalities in all scanned patients.

\section{Discussion}

Sinister aetiologies of SLUH were excluded among our patients. Primary headache was the most common headache category among patients with SLUH. Although, migraine constituted $60 \%$ of our study series, frequency of SLUH among migraineurs and those with nonmigraine headaches did not reach statistical significance (11.5\% vs $13 \%)$.

\section{Conclusion}

Before one could reach a conclusion of sinister aetiologies when faced with a patient with SLUH, primary headaches such as migraine and TTH should be considered.

Published: 21 February 2013

\section{References}

1. Chakravarty A, et al: . J Headache Pain 2008, 9:375-379.

2. International Headache Society: ICHD-II. Cephalalgia 2004, 24(Suppl 1).

doi:10.1186/1129-2377-14-S1-P64

Cite this article as: Momoh-Ojewuyi et al:: Side locked headaches. The Journal of Headache and Pain 2013 14(Suppl 1):P64.
Submit your manuscript to a SpringerOpen ${ }^{\circ}$ journal and benefit from:

- Convenient online submission

- Rigorous peer review

- Immediate publication on acceptance

- Open access: articles freely available online

- High visibility within the field

Retaining the copyright to your article

Submit your next manuscript at $>$ springeropen.com

\section{SpringerOpen ${ }^{\odot}$}

(C) 2013 Momoh-Ojewuyi et al; licensee Springer. This is an Open Access article distributed under the terms of the Creative Commons Attribution License (http://creativecommons.org/licenses/by/2.0), which permits unrestricted use, distribution, and reproduction in any medium, provided the original work is properly cited. 